\title{
The Effects of TGfU, SEM and HTGfU-SEM Towards Volleyball and Badminton Cognitive Game Play on Performance Among Form One Students
}

\author{
Noraliza Minhat \\ Faculty of Sport Science and Coaching, \\ Sultan Idris Education University \\ Sanmuga Nathan \\ Faculty of Sport Science and Coaching, \\ Sultan Idris Education University \\ Norkhalid Salimin \\ Faculty of Sport Science and Coaching, \\ Sultan Idris Education University
}

\begin{abstract}
The purpose of this study was to investigate the effects of Teaching games for Understanding (TGfU) as a control group compared to Sport Education Mode (SEM)I and Hybrid TGfU and Sport Education Model (HTGfU - SEM) as treatment groups in volleyball 3 vs 3 and badminton doubles game play. The effectiveness of these models were assessed based on cognitive tactical decision making of opening and closing space, selection of skill off digging, setting, blocking and spiking 3 vs 3 volleyball game play. As well as in opening and closing space and selection skills of forehand, lob shot and smash in badminton doubles game play. The research employed Quasi Experimental pre-post test design. A total of 96 students aged 13 years old were chosen intactly and distributed equally into three groups with 16 girls and 16 boys. The study utilized adopted Game Performance Assessment Instrument (GPAI) to access cognitive aspects of decision making. The data were analyzed using Mean, SD, ANOVA, ANCOVA, MANOVA and post-hoc test. As for the overall tactical decision making via multivariate test in volleyball and badminton double game play indicated significant through SEM. Especially for closing space in volleyball 3 vs 3 game play through SEM, F $(2,93)=$ $10.054, p<0.05, \eta 2=.178$. As well as significant improvement with SEM in opening space badminton double game play, with $F(2,93)=3.148, p<0.05, \eta 2=0.63$. Furthermore pairwise comparison indicated improvement through SEM for closing space with SEM, $p=2.031, p<0.05$. Therefore SEM is recommended as game play model for future learning cognitive aspects of tactical decision making in volleyball and badminton.
\end{abstract}

Keywords: Teaching Games for Understanding, Sport Education Model, Hybrid TGfU - SEM (HTGFU-SEM), cognitive domain, decision making.

\section{INTRODUCTION}

Teaching Games for Understanding (TGfU) model has been adopted in Malaysian Schools Standard Curriculum and Assessment (DSKP) for the Primary School Curriculum (KSSR) since 2011, while for Secondary School Curriculum (KSSM) since 2017. This model considered more holistic pedagogical approach for sports related game play globally. As many findings indicated TGfU able to improve tactical decision making and game enjoyment in Malaysia and globally [1]. However the limited research and implementation been conducted for extensive usage TGfU compared to othe learning model such as Sport Education Model (SEM) or hybrid combination model of TGfU - SEM in term of tactical decision making opening space, closing 
space and selection of skills across game play such volleyball and badminton. Therefore it's vital for country such Malaysia in the verge adapting $21^{\text {st }}$ century learning strategies which emphasizes on 5E learning approach of Engagement, Exploration, Explanation, Elaboration, and Evaluation [2] ought to try out different learning approaches, and not depend solely on TGfU.

As known TGfU model coined by Bunker and Thorpe in 1982. A student-centered instructional model and that focuses on game learning process [3]. The model aims to provide students with an understanding of the technical and tactical skills that have achieved success in various types of games as well as creating ongoing involvement [4]. The original TGfU model proposed by Bunker \& Thorpe (1982) [5] proposes six steps in game instruction namely game, game appreciation, tactical awareness, making appropriate decisions, skill execution and performance. TGfU do underpinning four pedagogical principles: sampling, representation, exaggeration and tactical complexity [6].

Meanwhile The Sport Education Model (SEM) was developed and introduced by Daryl Siedentop in 1994 [7]. The SEM is a curriculum and instruction model for the Physical Education (PE) program for the primary, secondary and tertiary level that focuses on students. The three main goals that guide development in the SEM are to produce competent, literate and enthusiastic students [7]. According to Siedentop [7], SEM has six main features: seasons, affiliation, formal competition, culminating event, record keeping and festivities. In this model all students are given a role in learning to become captains, coaches, team managers, trainers, tool managers, statistics, referees, scorers, public officials and sports board members to be seasonal and change [7].

Metzler stated that there were eight instructional models designed as an alternative to teachers in PE teaching among them Teaching Games for Understanding (TGfU) and Sports Education Model (SEM) [8] Teachers using TGfU instruction manipulate cognitive domains interesting so that that pupils learn the tactical aspects of the game through small sided games, real games and modified games according to the student's game progress [9]. Although cognitive domains are in importance skills, technical skills are simultaneously developed within tactically in context according to the complex pedagogical and tactical modification principles [10].

López, Práxedes, \& Villar [11] studied the effects of using the TGfU model on the tactical behavior of students in PE in secondary schools. Finding indicated pupils under the TGfU model achieved higher procedural knowledge. Meanwhile Hastie [12] states that the advantages of students participating in Sports Education Model increases investment in Physical Education, improving learning levels in game units and increasing opportunities for potential marginalized students. The investment is intended to be more skilled, increase the level of responsibility in the environment of interpersonal behavior and enjoyment with friends and make decisions freely without waiting for the direction of the teacher. The study of the game play approach (step by step) volleyball game affects the performance of high school students was conducted by Wallhead, Garn \& Vidoni [13] shows an increase in technical and tactical games. Another study by Mesquita, Farias, \& Hastie [14] is aimed at examining the impact of Hybrid Sport Education-Invasion Games Competence Model (SE-IGCM) applied to students in decision-making; The overall performance of the game during the soccer season indicates improved skill execution, as well as tactical decision making. The study of Hastie \& Curtner-Smith [15], TGfU and SEM are two curriculum models developed to help students participate in fair and equitable ways and challenge their thinking beyond technical replication and skills. 
Yet the extent to which the TGfU-based instruction in PE curriculum is implemented from a tactical aspect that allows students to learn tactical analysis in decision-making and is applied in modification games, real games and competitions. This gives researchers the opportunity to study between TGfU and SEM. The purpose of this study was to investigate the effectiveness of the three learning models (TGfU, SEM and HTGfU - SEM) in term tactical tactical decision making on opening space, closing space and skill selection (digging, setting, blocking, spiking) in volleyball 3 vs 3 game play. AS well as opening space, closing space and skill selection of forehand, lob shot, drop shot, smash badminton doubles game play. Therefore the study aimed to answer the following question is: - (i) Are there any instructional effects of TGfU, SEM and HTGfU - SEM Models towards tactical decision making on opening space and closing space using skills of digging, setting, blocking and spiking in 3 vs 3 volleyball game play at pre-post test? (ii) Are there any instructional effects of TGfU, SEM and HTGfU - SEM Models towards tactical decision making on opening space and closing space using skills of forehand, lob shot, drop shot, and smash in badminton doubles game at the pre-post test?. The SEM is aimed at producing competent, literate and passionate students about the game. According to Kirk [16], SEM is a model based on well-established and evidence-based pedagogy models where teachers focus on student-centered learning through cooperative and controversial pedagogy based on six features of the SE Model. The combination of components contained in TGfU and SEM is processed into Hybrid Teaching Games for Understanding - Sport Education Model (HTGfU - SEM) would be another alternative instructional model for game teaching as proposal in this study.

\section{Research Design}

\section{METHODOLOGY}

The research design employed in this study was quasi-experimental pre-post test with TGfU as control group while treatment group were SEM and HTGfU - SEM. Treatment groups and control groups were selected randomly by sampling. The simple random sampling techniques was employed to select a total of 96 students distributed into equally 48 male and 48 female of students of 13 years old and assigned distributed equally 32 students into TGfU, SEM and HTGfU - SEM.

\section{Intervension}

The instruction models used in this research were the Teaching Games for Understanding (TGfU) developed by Bunker \& Thorpe, (1982), SEM by Siedentop, (1994 ) and Hybrid Teaching Games for Understanding - SEM (Model HTGfU-SEM) by the researchers. These three instructional models were assessed in term of psychomotor domains, cognitive domains and affective domains in three on three volleyball games and doubles badminton game play. The learning and teaching component of each game involving five sessions in which each teaching and facilitating session is conducted within an hour (60 minutes). Lesson plans for the three models were planed based Malaysia Standard Curiculum for form one provided by Malaysia Ministry of Education [17].

The administration of study intervention for each model begins at second week, immediately after the pretest at first week. Briefing and training for instructors and research assistants were carried out before instructions intervention. Intervention begins at second week to fourth week for volleyball games. The fifth week was posttest for volleyball game play. The sixth week was pretest for a badminton game followed by intervention from the seventh to ninth week. The tenth week posttest for badminton was conducted. During the research, researchers ensure that all equipment and facilities used was in good condition and safe to use to ensure the safety of the students in a controlled manner. 


\section{Instruments}

The instrument used in this study is the Game Performance Assessment Instrument (GPAI) by Mitchell, Oslin \& Griffin (2005) which was also modified by Sanmuga Nathan [3] from the study of the category of attack game (hockey). These modified instruments are used to assess cognitive aspects of volleyball and badminton games.

\section{Result for Cognitive Domain (Volleyball)}

\section{RESULTS}

As far the results of The effect of the instruction is based on TGfU, SEM and HTGfU - SEM in the aspect of tactical decision making open space and closing space and making decisions using skills for digging, setting, blocking, and spiking in a three on three volleyball game (3 vs 3) pretest and postest.

The findings of the pretest showed that there was no significant difference between instruction models of TGfU, SEM and HTGfU-SEM in cognitive aspect, namely making tactical decision on opening space and closing space and on deciding of using skills for digging, setting, blocking, spiking in volleyball game $(\mathrm{F}(6,000,182,000)=31.129 \mathrm{~b}, \mathrm{p}<.05$; Wilk's $\Lambda=.930$, partial $\eta 2=$ .036). ANOVA's univariate results too of these on three models on tactical decision making opening space $(F(2,93)=1.928 ; p>.05$, partial $\eta 2=.040)$, closing space $(F(2,93)=.231 ; p>$ .05 , partial $\eta 2=.005)$, decision making using skill $(F(2,93)=.090 ; p>.05$, partial $\eta 2=.002)$, also indicated no significant difference at pre-test as reflected in Table 2 and 3.

Table 1. Min Score Pretest and Posttest in Decision Making Volleyball Cognitive Game Play

\begin{tabular}{lccccccc}
\hline \multirow{2}{*}{ Model } & \multirow{2}{*}{$\begin{array}{c}\text { Decision } \\
\text { making }\end{array}$} & \multicolumn{3}{c}{ Pretest } & \multicolumn{3}{c}{ Posttest } \\
\cline { 3 - 8 } & & Min & SD & N & Min & SD & N \\
\hline TGfU & & 1.84 & .628 & 32 & 2.47 & .567 & 32 \\
SEM & Open space & 1.84 & .628 & 32 & 2.78 & .608 & 32 \\
HTGfU - SEM & & 1.59 & .499 & 32 & 2.66 & .602 & 32 \\
\hline TGfU & & 1.62 & .660 & 32 & 2.59 & .499 & 32 \\
SEM & Close space & 1.53 & .507 & 32 & 2.91 & .689 & 32 \\
HTGfU - SEM & & 1.56 & .504 & 32 & 2.28 & .457 & 32 \\
\hline TGfU & & 1.81 & .738 & 32 & 2.66 & .483 & 32 \\
SEM & & 1.78 & .553 & 32 & 3.03 & .740 & 32 \\
HTGfU - SEM & & 1.75 & .440 & 32 & 2.78 & .608 & 32 \\
\hline
\end{tabular}

* Teaching Games for Understanding Model (TGfU)

* Sport Education Model (SEM)

* Hibrid Teaching Games for Understanding - Sport Education Model (HTGfU-SEM)

Table 2. Multivariate Test at the Volleyball Game Pretest

\begin{tabular}{llcccccc}
\hline & \multicolumn{1}{c}{ Effect } & Value & $\boldsymbol{F}$ & Hypothesis df & Error df & Sig. & Partial eta $^{2}$ \\
\hline Groups & Pillai's Trace & .071 & 1.127 & 6.000 & 184.000 & .348 & .035 \\
& Wilks' Lambda & .930 & $1.129 \mathrm{~b}$ & 6.000 & 182.000 & .347 & .036 \\
& Hotelling's Trace & .075 & 1.131 & 6.000 & 180.000 & .346 & .036 \\
& Roy's Largest Root & .069 & $2.130^{\mathrm{c}}$ & 3.000 & 92.000 & .102 & .065 \\
\hline
\end{tabular}


Table 3. Univariate tests of cognitive ANOVA Decision Making on the Volleyball Game Pretest

\begin{tabular}{|c|c|c|c|c|}
\hline Dependent Variables & $d f$ & $F$ & Sig. & Partial eta $^{2}$ \\
\hline Open space & $\begin{array}{c}2 \\
93\end{array}$ & 1.928 & .151 & .040 \\
\hline Close Space & $\begin{array}{c}2 \\
93\end{array}$ & .231 & .794 & .005 \\
\hline Decision making using skills & $\begin{array}{c}2 \\
93\end{array}$ & .090 & .914 & .002 \\
\hline
\end{tabular}

There was overall significant difference on decision making among the model at posttest using multivariate test as in Table 4. However based on ANOVA's univariate results indicated there were no significant difference among the models in terms open space $(F(2,93)=2.255 ; p>.05$, partial $\eta 2=.046$ ) decision making skills of digging, setting, blocking and spiking in 3 vs 3 game play. However there was significant and improvement for decision making on closing space with SEM $(F(2,93)=10.054 ; p<.05$, partial $\eta 2=.178)$ as in Table 5 .

Post-hoc comparative test results based on adjusted mean Bonferroni for cognitive aspect of tactical decision making in volleyball for opening space shows no significant difference between TGfU with SEM, $p=.626(\mathrm{p}>.05)$ no significant difference between TGfU with HTGfUSEM, $p=.113(p>.05)$ also no significance and HTGfU - SEM with SEM, $p=1.000(p>.05)$. The cognitive aspect of volleyball of closing space TGfU with HTGfU - SEM, $p=0.82(p>.05)$ no significant, TGfU with SEM, $p=.082(\mathrm{p}>.05)$ also no significant while HTGfU - SEM with SEM, $p$ $=.000(\mathrm{p}<.05)$ shows a significant difference. Next the cognitive aspect decision; making on the selection of volleyball skills shows the findings of TGfU with HTGfU - SEM, p = $1.000(p>$ $.05)$ indicated no significant, TGfU with SEM, $\mathrm{p}=.052(\mathrm{p}>0.05)$ also no significant and HTGfU SEM with SEM, $\mathrm{p}=.329(\mathrm{p}>.05)$ also indicated no significant too.

Table 4. Multivariate Test at the Volleyball Game Posttest

\begin{tabular}{llcccccc}
\hline & \multicolumn{1}{c}{ Effect } & Value & $\boldsymbol{F}$ & Hypothesis $\boldsymbol{d f}$ & Error df & Sig. & Partial eta $^{2}$ \\
\hline Groups & Pillai's Trace & .265 & 4.674 & 6.000 & 184.000 & .000 & .132 \\
& Wilks' Lambda & .747 & $4.761^{\mathrm{b}}$ & 6.000 & 182.000 & .000 & .136 \\
& Hotelling's Trace & .323 & 4.846 & 6.000 & 180.000 & .000 & .139 \\
& Roy's Largest Root & .264 & $8.106^{\mathrm{c}}$ & 3.000 & 92.000 & .000 & .209 \\
\hline
\end{tabular}

Table 5. Univariate tests of cognitive ANOVA Decision Making on the Volleyball Game Posttest.

\begin{tabular}{lcccc}
\hline Dependent Variables & $\boldsymbol{D f}$ & $\boldsymbol{F}$ & Sig. & Partial eta $^{\mathbf{2}}$ \\
\hline Open space & 2 & 2.255 & .111 & .046 \\
Close Space & 93 & & & \\
& 2 & 10.054 & .000 & .178 \\
$\begin{array}{l}\text { Decision making using } \\
\text { skills }\end{array}$ & 93 & & & \\
\hline
\end{tabular}

\section{Result for Cognitive Domain (Badminton)}

The effect of TGfU, SEM and HTGfU-SEM in terms of tactical decision making open space and closing space and making decisions of selection skills for forehand, lob shot, drop shot and smash in a double badminton game at the pretest and posttest as reflected in Table 6, 7 and 8. 
The overall findings at the pre-test showed that there was significant differences between instruction models of TGfU, SEM and HTGfU - SEM in cognitive aspect of decision-making in open space tactics and decision making of choosing skills of forehand, lob shot, drop shot and smash in badminton $(F(6,000,182,000)=6.323 b, p<.05$; Wilk's $\Lambda=.684$, partial $\eta 2=.036)$ at posttest. However, based on ANOVA's univariate results for all three models, as for decision making opening space results indicated significant differences $(F(2,93)=3.148 ; \mathrm{p}<.05$, partial $\eta 2=.063)$. However there was no significant difference for close space $(F(2,93)=1,021 ; p>$ .05 , partial $\eta 2=.021$ ) and decision making on selection badminton skills of forehand, lob shot, drop shot and smash $(F(2,93)=1.326 ; p>.05, \eta 2=.028)$.

Table 6. Min Score Pretest and Posttest in Decision Making Badminton Cognitive Game Play

\begin{tabular}{|c|c|c|c|c|c|c|c|}
\hline \multirow[b]{2}{*}{ Model } & \multirow{2}{*}{$\begin{array}{c}\text { Decision } \\
\text { making }\end{array}$} & \multicolumn{3}{|c|}{ Pretest } & \multicolumn{3}{|c|}{ Posttest } \\
\hline & & Min & SD & $\mathrm{N}$ & Min & SD & $\mathrm{N}$ \\
\hline TGfU & & 2.54 & .567 & 32 & 3.09 & .296 & 32 \\
\hline SEM & Open space & 2.31 & .471 & 32 & 3.00 & .718 & 32 \\
\hline HTGfU - SEM & & 2.22 & .491 & 32 & 3.31 & .471 & 32 \\
\hline TGfU & & 2.31 & .535 & 32 & 3.06 & .504 & 32 \\
\hline SEM & Close space & 2.31 & .471 & 32 & 2.97 & .695 & 32 \\
\hline HTGfU - SEM & & 2.47 & .507 & 32 & 3.34 & .545 & 32 \\
\hline TGfU & & 2.41 & .756 & 32 & 3.16 & .448 & 32 \\
\hline SEM & Using skills & 2.69 & .693 & 32 & 3.25 & .718 & 32 \\
\hline HTGfU - SEM & & 2.53 & .621 & 32 & 3.47 & .671 & 32 \\
\hline
\end{tabular}

* Teaching Games for Understanding Model (TGfU)

* Sport Education Model (SEM)

* Hibrid Teaching Games for Understanding - Sport Education Model (HTGfU-SEM)

Table 7. Multivariate Test at the Badminton Game Pretest

\begin{tabular}{llccccccc}
\hline & \multicolumn{1}{c}{ Effect } & Nilai & $\boldsymbol{F}$ & Hypothesis $\boldsymbol{d f}$ & Error df & Sig. & Partial eta $^{2}$ \\
\hline \multirow{2}{*}{ Groups } & Pillai's Trace & .335 & 4.674 & 6.000 & 184.000 & .000 & .132 \\
& Wilks' Lambda & .684 & $6.343^{\mathrm{b}}$ & 6.000 & 182.000 & .000 & .173 \\
& Hotelling's Trace & .433 & 4.846 & 6.000 & 180.000 & .000 & .139 & .209 \\
\hline
\end{tabular}

Table 8. Univariate tests of cognitive ANOVA Decision Making on the Badminton Game Pretest

\begin{tabular}{|c|c|c|c|c|}
\hline Dependent Variables & $\overline{D f}$ & $F$ & Sig. & Partial eta $^{2}$ \\
\hline Open space & $\begin{array}{c}2 \\
93\end{array}$ & 3.148 & .048 & .063 \\
\hline Close Space & $\begin{array}{c}2 \\
93\end{array}$ & 1.021 & .364 & .021 \\
\hline $\begin{array}{l}\text { Decision making using } \\
\text { skills }\end{array}$ & $\begin{array}{c}2 \\
93\end{array}$ & 1.326 & .270 & .028 \\
\hline
\end{tabular}

Due to the fact that the overall MANOVA test as in Table 9 indicated significant difference at pretest, the researcher used MANCOVA for the post-test study was using the MANCOVA test report. Based on MANOVA Multivariate test analysis, there was significant differences between 
instruction based on TGfU, SEM and HTGfU - SEM in the overall aspect of cognitive component ie open space, space closure and decision making using badminton skills $(F(6.000,176.000)=$ 2.638a, $\mathrm{p}<.05$; Wilk's $\Lambda=.842$, partial $\eta 2=.083$ ). The overall finding of MANCOVA was supported based on ANOVA's univariate test results for all three models. There were a significant difference for open space $(F(2,90)=4.054 ; p<.05$, partial $\eta 2=.083)$ and close space $(F(2,90)=6.031 ; p<.05$, partial $\eta 2=.118)$ at posttest. However there was no significant difference in decision making using the skills of forehand, lob shot, drop shot and smash $(F(2,90)=2.896 ; p>.05$, partial $\eta 2=.060)$ as Table 10 .

Furthermore in post-hoc comparison results based on adjusted mean of Bonferroni for cognitive aspect of badminton; open decision making on space shows no significant difference to all three instruction models; TGfU with HTGfU - SEM, $\mathrm{p}=.296(\mathrm{p}<.05)$, TGfU with SEM, $\mathrm{p}=$ $.1000(\mathrm{p}>.05)$ and HTGfU-SEM with SEM, $\mathrm{p}=.058(\mathrm{p}>.05)$. While decision making closing space results also show no significant difference for TGfU with HTGfU - SEM, $p=.175$ ( $p>.05)$ and TGfU with SEM, $p=1.000(p>.05)$. However there was a significant difference in HTGfU SEM compared to SEM in closing space, $p=.037(\mathrm{p}<.05)$. The result of the tactical decision on the selection of volleyball skills shows that there was no significant difference $(p>.05)$ for TGfU with HTGfU - SEM, $\mathrm{p}=.144$, TGfU with SEM, $\mathrm{p}=1.000$ and HTGfU - SEM with SEM, $\mathrm{p}=$ .492 .

Table 9. Multivariate MANCOVA Test at the Badminton Game Posttest

\begin{tabular}{llcccccc}
\hline & \multicolumn{1}{c}{ Effect } & Nilai & $\boldsymbol{F}$ & Hypothesis df & Error df & Sig. & Partial eta $^{2}$ \\
\hline \multirow{2}{*}{ Kump } & Pillai's Trace & .161 & 2.605 & 6.000 & 178.000 & .019 & .081 \\
& Wilks' Lambda & .842 & $2.638^{\mathrm{a}}$ & 6.000 & 176.000 & .018 & .083 \\
& Hotelling's Trace & .184 & 2.670 & 6.000 & 174.000 & .017 & .084 \\
& Roy's Largest Root & .160 & $4.756^{\mathrm{b}}$ & 3.000 & 89.000 & .004 & .138 \\
\hline
\end{tabular}

Table 10. Univariate tests of cognitive ANOVA Decision Making on the Badminton Game Posttest

\begin{tabular}{lcccc}
\hline Dependent Variables & $\boldsymbol{d} \boldsymbol{f}$ & $\boldsymbol{F}$ & Sig. & Partial eta $^{2}$ \\
\hline Open space & 2 & 4.054 & .021 & .083 \\
Close Space & 90 & & & .003 \\
& 2 & 6.031 & & .060 \\
$\begin{array}{l}\text { Decision making using } \\
\text { skills }\end{array}$ & 90 & 2.896 & .060 & \\
\hline
\end{tabular}

\section{DISCUSSION}

The findings of the present study showed that there were a significant improvement via SEM in volleyball in term of decision making of closing space 3 vs 3 volleyball game play. Whereas findings for tactical decision making opening space indicated significant improvement through SEM for badminton double game play.

The present study findings on tactical decision making for closing space volleyball and opening space badminton in line with sudy by Malathi, Shabeshan \& Salleh [18] that TGfU stimulates student cognitive aspects of tactical understanding and learning decision making. As TGfU approach is applied in modified games to make pupils' understanding better with the game being learned. Tactical transfer and decision making to real games will be easy as the game base is understood and mastered through small sided game play. Next the use of GPAI on cognitive aspects of tactical decision-making and choice of skills in current studies, support the research by Harvey, Cushion, Wegis, \& Massa-Gonzalez [19] as they conducted a study on the 
use of Game Performance Assessment Instrument (GPAI) via TGfU instruction. That TGfU's learning and teaching led to quick response and faster response in game situations whereby the current study findings showed increased in space-gap tactical decision-making with SEM and increased in decision making on closing space volleyball and opening space (badminton). Therefore, GPAI is more sensitive and robust in measuring game performance changes, therefore this study to support the important of GPAI to assess game play performance.

In the SEM instruction students were given the opportunity in cognitive thinking to make tactical decisions and increase for playing and managing the game. This helps to increase the cognitive aspect of tactical decision making in opening space, closing space through tactical options. By this SEM instruction, facilitators able to assist in the learning process by throwing questions and commenting on the game. When opportunities are created for pupils, they have the freedom to think and to make right tactical decisions in the closing and opening space and the choice of skills then the cognitive process has taken place. Therefore this finding support the theory of Constructivism and Complex Learning theory that underlies these two theories of Constructivism Theory by Jean Piaget and Lev Vygotsky emphasize the development of knowledge through the process of interdependence between previous learning and related new learning [20]. The emphasis of these theories can be interpreted through the planning of student strategy game planning, decision making skills in the game and making reflection on learning. Complex Learning Theory by Davis and Sumara (2003) has highlighted the importance of Complex Learning Theory to solve problems or to carry out tasks, and facilitate the transfer of what has been learned for task and problem situations. This theory underline integration of knowledge, skills and attitudes as a competence in deciding the solution of a problem involving the formulation of tactical games and facilitating the transfer of something learned by the diversity of situations during the game [21]

The current study sample has a wide range of skill levels and game gratification that is low, medium and good. Through the SEM, it helps to improve the ability of low-skilled pupils to create and implement tactical decision-making, space closures and more cooperative skills based on their learning through teammates who have mastered the diversity of skills [22]. The results of the present study are consistent with findings of Mesquita et al. [14] and Mahedero, Calderón, Arias-Estero, Hastie, \& Guarino [21] demonstrate the use of TGfU hybrid models and Sports Education giving students the opportunity to improve their skills, and tactical decisions.

However, based on the findings of the present study, cognitive aspects of decision making in the selection of skills were not significant in all three of these models with volleyball and badminton game play. The findings are likely to have a short duration of teaching involving five teaching sessions within a three-week period. Students cannot master the entire learning process in the development of mastery of decision making skills usage in the game play. Types of actions to be trained more tactically or technically to match the training session methodology and effective teaching approaches, should be used over a longer period of at least 22 sessions [23]. The findings of the current study contrast with the study of López, Práxedes, \& Villar [24] the effects of using the TGfU teaching model on tactical behavior of students as there was no significant improvement in decision making and performance in real games that may be affected by the program's duration.

The readiness of teachers to receive and understand the various game play instructions should be emphasized. Learning games is a process that must be tailored to the potential of the student. Therefore, in order to adapt teaching practices to students' motivation, as well as their capabilities, a new ecological teaching model has emerged to promote student practice and provide instruction options to physical education teachers [25]. Focusing only TGfU Model in 
Malaysia, teachers find it difficult to implement them, as students need situational guidance to discuss tactical aspects and to maintain this pedagogical model, adopted TGfU research findings should be disseminated among teachers in Malaysia and Asian countries [1].

In summary, the findings of the current study, SEM instruction illustrate the reasonableness and suitable to be implemented in Malaysia with activities modified as in improving cognitive learning process in aspects of tactical decision making of opening space and closing space in the game play. Therefore anecdotal findings SEM development of cognitive improvement indirectly contributes to the enhancement of skills in game play.

\section{CONCLUSION AND FUTURE AGENDA}

In conclusion, the findings of the current study on TGfU, SEM and HTGfU - SEM indicated that SEM has important content to cause this model to be used in the future in the game curriculum. SEM reworked with TGfU combination can be too used for learning game. The possibilities of the study have found that SEM can stand alone to assist in the improvement of tactical decision-making capability, opening space and closing space in the game. The re-processed SEM with TGfU combination can be used in learning game. SEM is more flexible and can be combined with another model as one of the instruction models. This current study suggests that SEM is better approach for decision making but the extent to which SEM can be applied across the country allows further studies to be made. Perhaps further studies can use replicate this study to be conducted against SEM compatibility with TGfU and HTGfU - SEM.

\section{References}

Nathan, S. (2016). Badminton instructional in Malaysian schools: a comparative analysis of TGfU and SDT pedagogical models. SpringerPlus, 5(1). http://doi.org/10.1186/s40064-016-2872-3.

Kementerian Pendidikan Malaysia. (2015). Pendidikan Jasmani dan Pendidikan Kesihatan (Dokumen Standard Kurikulum dan Pentaksiran) Tingkatan 1. Kementerian Pendidikan Malaysia.

Nathan, S. (2014). Instruksi Model Taktikal Permainan. PTS Akademia, Malaysia..

Mandigo, J. L., \& Holt, N. L. (2004). Reading the game: Introducing the notion of gammes literacy. Physical and Health Educational Journal, 70(3), 4-10.

Bunker, D., \& Thorpe, R. (1982). A model for the teaching of games in secondary schools. Bulletin of Physical Education, 18..

Griffin, L. L., Brooker, R., \& Patton, K. (2005). Working towards legitimacy: two decades of teaching games for understanding. Physical Education \& Sport Pedagogy, 10(3), 213-223.

http://doi.org/10.1080/17408980500340703.

Siedentop, D. (1994). Sport Education: Quality PE Through Positive Sports Experiences. Human Kinetics Publishers.

Metzler, M. (2011). Instructional Model for Physical Education (3rd ed.). Scottsdale,AZ: Holcomb Hathaway.

Harvey, S., \& Jarrett, K. (2014). A review of the game-centred approaches to teaching and coaching literature since 2006. Physical Education and Sport Pedagogy, 19(3), 278-300. http://doi.org/10.1080/17408989.2012.754005.

Werner, P., Thorpe, R., \& Bunker, D. (1996). Teaching Games for Understanding: Evolution of a Model. Journal of Physical Education, Recreation \& Dance, 67(1), 28-33. http://doi.org/10.1080/07303084.1996.10607176.

López, I., Práxedes, A., \& Villar, F. del. (2016). Effect of an intervention teaching program, based on TGfU model, on the cognitive and execution variables, in the Physical Education context. European Journal of Human Movement, 37(0), 88-108.

Hastie, P. (1998). Applied Benefits of the Sport Education Model. Journal of Physical Education, Recreation \& Dance, 69(4), 24-26. http://doi.org/10.1080/07303084.1998.10605530.

Wallhead, T. L., Garn, A. C., \& Vidoni, C. (2014). Effect of a sport education program on motivation for physical education and leisure-time physical activity. Research Quarterly for Exercise and Sport. Taylor \& Francis. http://doi.org/10.1080/02701367.2014.961051. 
Mesquita, I., Farias, C., \& Hastie, P. (2012). The impact of a hybrid Sport Education-Invasion Games Competence Model soccer unit on students' decision making, skill execution and overall game performance. European Physical Education Review, 18(2), 205-219. http://doi.org/10.1177/1356336X12440027.

Hastie, P. A., \& Curtner-Smith, M. D. (2006). Influence of a hybrid Sport Education-Teaching Games for Understanding unit on one teacher and his students. Physical Education \& Sport Pedagogy, 11(1), 1-27. http://doi.org/10.1080/17408980500466813

Kirk, D. (2013). Educational Value and Models-Based Practice in Physical Education Educational Value and Models-Based Practice in Physical Education. Educational Philosophy and Theory, 45(9), 873-986. http://doi.org/10.1080/00131857.2013.785352.

Kementerian Pendidikan Malaysia. (2015). Pendidikan Jasmani dan Pendidikan Kesihatan (Dokumen Standard Kurikulum dan Pentaksiran) Tingkatan 1. Kementerian Pendidikan Malaysia.

Malathi, B., Shabeshan, R., \& Mohd Salleh, A. (2011). Effect of Teaching Games for Understanding Approach on Students' Cognitve Learning Outcome. World Academy of Science, Engineering and Technology, 163-166.

Harvey, S., Cushion, C. J., Wegis, H. M., \& Massa-Gonzalez, A. N. (2010). Teaching Games for Understanding In American High-School Soccer: A Quantitative Data Analysis Using The Game Performance Assessment Instrument. Physical Education \& Sport Pedagogy, 15(1), 29-54. http://doi.org/10.1080/17408980902729354.

Schunk, D. H. (2012). Learning Theories: An Educational Perspective (6th ed.). Pearson.

Mahedero, P., Calderón, A., Arias-Estero, J. L., Hastie, P. A., \& Guarino, A. J. (2015). Effects of Student Skill Level on Knowledge, Decision Making, Skill Execution and Game Performance in a Mini-Volleyball Sport Education Season. Journal of Teaching in Physical Education, 34(4), 626-641. http://doi.org/10.1123/jtpe.2014-0061.

Hastie, P. A., Sinelnikov, O. A., \& Guarino, A. J. (2009). The development of skill and tactical competencies during a season of badminton. European Journal of Sport Science, 9(3), 133-140. http://doi.org/10.1080/17461390802542564.

del Villar Álvarez, F., \& Práxedes Pizarro, A. (2017). The effects of a comprehensive teaching program on dribbling and passing decision-making and execution skills of young footballers. Kinesiology, 49(1), 74-83.

http://doi.org/10.26582/k.49.1.6.

López, I., Práxedes, A., \& Villar, F. del. (2016). Effect of an intervention teaching program, based on TGfU model, on the cognitive and execution variables, in the Physical Education context. European Journal of Human Movement, 37(0), 88-108.

Clemente, F., Filipe Rocha, R., \& Korgaokar, A. (2012). Teaching physical education: the usefulness of the teaching games for understanding and the constraints-led approach. Journal of Physical Education and Sport $₫($ JPES), 12(4), 417-426. http://doi.org/10.7752/jpes.2012.04062. 